\title{
Retained Rice Cake: A Unique Upper Gastrointestinal Foreign Body: Case Report and a Literature Review
}

\author{
Akihiko Oka ${ }^{1-3}$, Shunji Ishihara ${ }^{2,4}$, Hironobu Mikami ${ }^{2,5}$, Hiroki Sonoyama ${ }^{2}$, \\ Tsuyoshi Mishiro ${ }^{2,5}$, Hiroshi Tobita ${ }^{2}$, Kousaku Kawashima ${ }^{2,4}$, Tatsuya Miyake ${ }^{2,6}$, \\ Norihisa Ishimura $^{2}$, Kenji Furuta ${ }^{2,7}$, Yoshikazu Kinoshita ${ }^{2}$ and Masayoshi Nishina ${ }^{1}$
}

\begin{abstract}
:
As a rarely recognized foreign body in the upper gastrointestinal tract, rice cake frequently requires endoscopic removal. We herein report six patients with characteristic sonography, computed tomography (CT), spectroscopy, endoscopy, and histological findings. A review of all published cases, including ours, revealed that retained rice cake in the stomach typically shows the following: abdominal pain (93.3\%), mucosal injury (93.3\%) with bleeding (42.9\%); high-density (120-206 Hounsfield units) CT findings; and indication for endoscopy $(80 \%)$. In the esophagus, hot, toasted rice cake causes thermal injury. Primary physicians should be aware of this popular-food-induced, but rare, disorder.
\end{abstract}

Key words: rice cake, foreign body, mucosal injury, obstruction, upper gastrointestinal tract, thermal injury

(Intern Med 58: 2485-2494, 2019)

(DOI: 10.2169/internalmedicine.2760-19)

\section{Introduction}

Most ingested foreign bodies (80-90\%) pass through the gastrointestinal (GI) tract spontaneously without clinical complications $(1,2)$. However, $10-20 \%$ require nonoperative intervention, and $1 \%$ eventually require surgery $(1,3)$. Since the therapeutic approach and clinical course vary depending on the type of foreign body (1-3), an accurate diagnosis and identification of the type of foreign body are necessary. The most common types of food-related foreign bodies in the GI tract are meat bolus impactions $(4,5)$ and bezoars associated with persimmon ingestion $(1,6)$. Rice cake (mochi), which is an extremely popular food in east Asia (7-9), is a rare type of foreign body but can cause GI obstruction, bleeding, and perforation (9-11). Although airway obstruction by rice cake is well recognized $(7,8)$, a GI foreign body associated with rice cake is poorly recognized because of its rar- ity (9-12).

We herein report six cases of retained rice cake as a gastric foreign body along with characteristic and diagnostic clinical images.

\section{Case Reports}

\section{Case 1}

A 68-year-old woman was referred to our gastroenterology department with upper abdominal colicky pain and vomiting. She had eaten a toasted rice cake without chewing well because of her dentures the day before. Her vital signs were within normal limits. Laboratory testing showed a slightly elevated white blood cell (WBC) count of 9,160 cells/ $\mathrm{LL}$ (normal 3,300-8,600) with other blood cell counts within normal limits, hemoglobin $(\mathrm{Hb}) 14.7 \mathrm{~g} / \mathrm{dL}$ (normal 11.0-14.8), C-reactive protein (CRP) $0.09 \mathrm{mg} / \mathrm{dL}$ (normal <

${ }^{1}$ Department of Emergency and Critical Care Medicine, Shimane University, Faculty of Medicine, Japan, ${ }^{2}$ Department of Internal Medicine II, Shimane University, Faculty of Medicine, Japan, ${ }^{3}$ Center for Gastrointestinal Biology and Disease, Department of Medicine, Division of Gastroenterology and Hepatology, University of North Carolina at Chapel Hill, USA, ${ }^{4}$ Inflammatory Bowel Disease Center, Shimane University Hospital, Japan, ${ }^{5}$ Division of Gastroenterology, National Hospital Organization Hamada Medical Center, Japan, ${ }^{6}$ Division of Hepatology, Shimane Prefectural Central Hospital, Japan and ${ }^{7}$ Otsu Internal Medicine Clinic, Japan

Received: January 28, 2019; Accepted: March 11, 2019; Advance Publication by J-STAGE: June 7, 2019

Correspondence to Dr. Akihiko Oka, akihiko_oka@med.unc.edu 

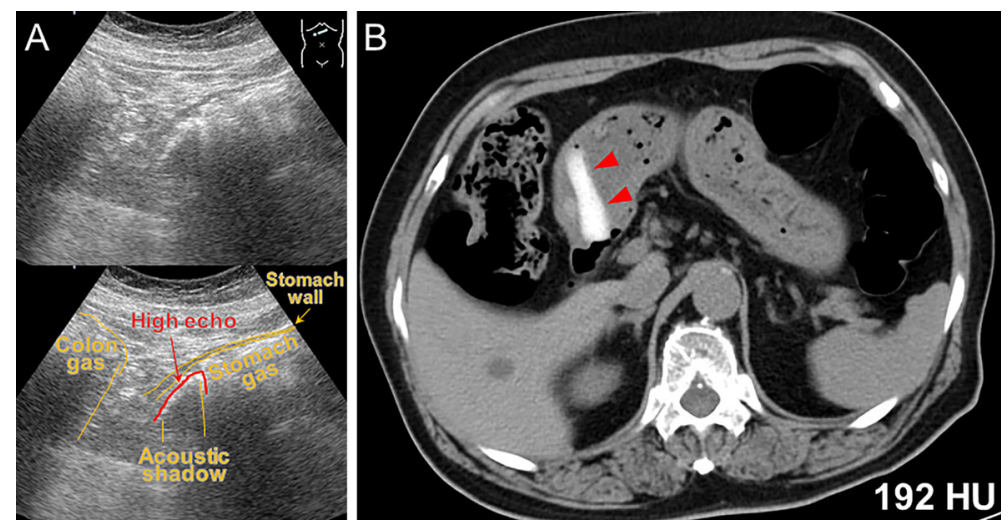

Figure 1. Sonography and computed tomography (CT) images from Case 1 (68-year-old woman). (A) Upper abdominal sonogram showing hyperechoic arc-like echo with acoustic shadowing in the gastric antrum. (B) Plain CT image demonstrating 4.5-cm-long high-density object (red arrowheads) in the gastric antrum. CT number=192 Hounsfield units (HU) (window width: 30; window level: 300; region of interest: $20 \mathrm{~mm}^{2}$ ).
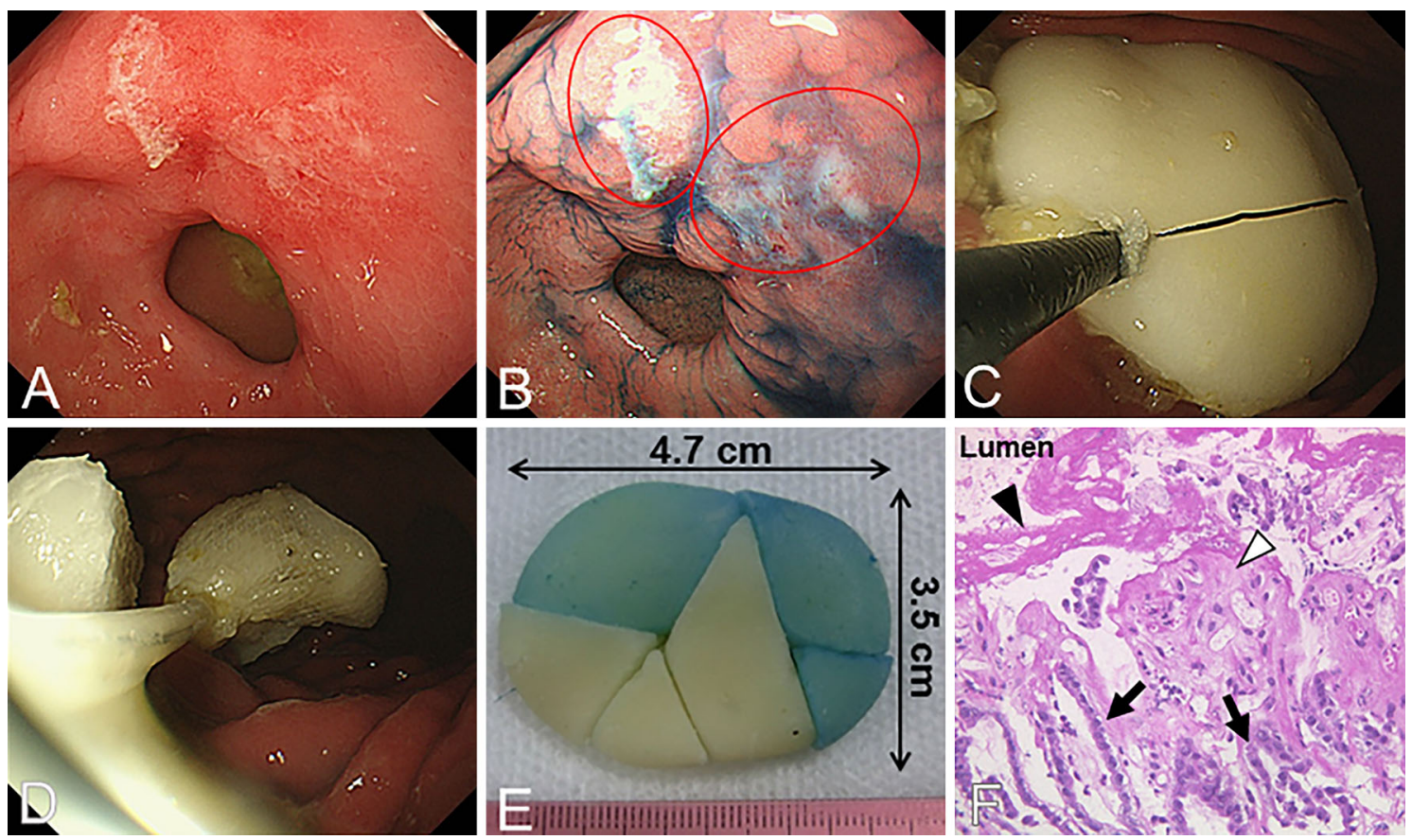

Figure 2. Endoscopic and histological images from Case 1 (68-year-old woman). (A) Endoscopy image showing multiple erosions in the gastric antrum. (B) Endoscopy image with indigo-carmine dye emphasizing area of erosions (red circles). (C) Endoscopy image of snare excision without application of electrical current, cutting the retained rice cake into small pieces (Olympus snare SD-5). (D) Endoscopy image of the removal of the rice cake with an endoscopic net (Olympus-00711180). (E) Photo of the removed pieces of rice cake. The blue color was due to indigo-carmine dye. (F) Photomicrograph of a biopsy of a gastric erosion site showing epithelial shedding and exudate (black arrowhead) with ischemic changes, such as edematous stromal tissue (white arrowhead), diffuse loss of epithelium (ghost-like appearance) and regenerative changes (high nuclear/cytoplasmic ratio, black arrows). Hematoxylin and Eosin staining, 100x

0.2). A physical examination revealed a mildly tender upper abdomen. Abdominal sonography in the area of tenderness demonstrated a 4- to 5-cm hyperechoic, arc-like echo with acoustic shadowing in the gastric antrum (Fig. 1A). Computed tomography (CT) detected a high-density image of
192 Hounsfield units (HU) in the gastric antrum that extended into the duodenum (Fig. 1B). Endoscopy revealed a large, hard, white foreign body $(4.7 \times 3.5 \mathrm{~cm})$, representing an undigested rice cake, and multiple erosions in the gastric antrum (Fig. 2A and B). The large rice cake was cut into 

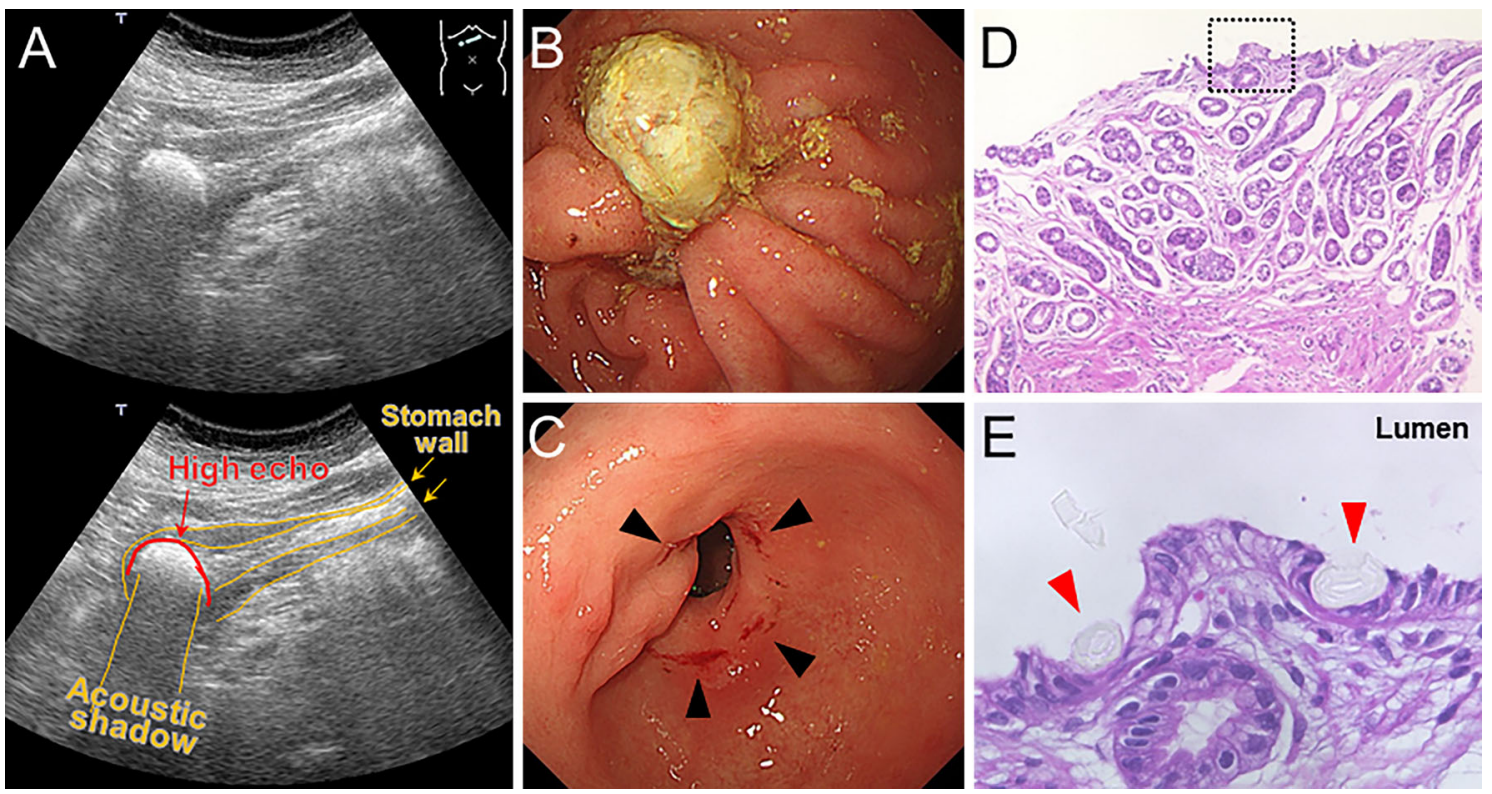

Figure 3. Sonography, endoscopy, and histological images from Case 2 (59-year-old woman). (A) Upper abdominal sonogram showing hyperechoic arc-like echo with acoustic shadowing in the gastric antrum. (B, C) Endoscopy images revealing rice cake adherent to the pyloric ring and circular erosions (black arrowheads) on the pyloric ring. (D) Photomicrograph demonstrating ischemic changes. Hematoxylin and Eosin (H\&E) staining, 100x. (E) Enlarged photomicrograph of square in panel D showing crystalline starch particle in the epithelial layer. H\&E staining, 200x

small pieces with an endoscopic snare without the application of electrical current (Fig. 2C), and all the pieces of the cake were removed using an endoscopic net (Fig. 2D and E). The patient's pain and vomiting rapidly disappeared after the procedure. A histological assessment of biopsy samples from the erosions confirmed the absence of malignant changes and presence of ischemic changes (Fig. 2F), indicating that mechanical compression by the hard rice cake led to mucosal ischemia. The gastric erosions were successfully treated with an antiulcer agent (rabeprazole). The patient was advised to chew her food well, especially rice cakes, and at the time of this writing, she had not experienced any similar GI obstructions.

\section{Case 2}

An otherwise healthy 59-year-old woman presented to our emergency department with upper abdominal colicky pain. She had eaten a toasted rice cake without chewing well because of her dentures the day before. Her vital signs, physical examination findings, and laboratory tests were within normal limits. Sonography showed a 2-cm hyperechoic, arclike echo in the gastric antrum (Fig. 3A). Endoscopy revealed a large, hard, white rice cake obstructing the pyloric ring and strong peristaltic contractions (Fig. 3B). Removal of the rice cake revealed multiple round erosions on the pyloric ring (Fig. 3C). A histological assessment of the biopsy samples from the pyloric erosions revealed ischemic changes in the mucosa (Fig. 3D). In addition, crystal-like starch particles were seen in the epithelial layer (Fig. 3E), indicating that the rice cake had been strongly pressed against the mu- cosa. To confirm that the foreign body was a rice cake, infrared spectroscopy (SRL, Hachioji, Japan) was performed, revealing that the spectra of the foreign body were similar to that of commercial rice cake (Fig. 4) as well as that of amylopectin (13), which is the main component of rice cake. The patient's abdominal pain disappeared quickly after the removal of the rice cake. The erosions were successfully treated with rabeprazole, without recurrence.

\section{Case 3}

A 70-year-old woman presented to our emergency department with upper abdominal colicky pain and vomiting. She had dentures and had eaten a boiled rice cake 5 hours previously. Her vital signs and laboratory tests were within normal limits. A physical examination revealed mild tenderness of the upper abdomen. CT showed high-density objects (140 $\mathrm{HU}$ ) of 3.5 and $1 \mathrm{~cm}$ in the stomach (Fig. 5A). Endoscopy revealed three pieces of rice cake in the gastric fornix, bloody gastric contents, and multiple circular erosions on the pyloric ring (Fig. 5B and C). All pieces of rice cake were removed with an endoscopic net (Fig. 5D). Her signs and symptoms disappeared quickly after the removal of the rice cake pieces. The erosions were successfully treated with rabeprazole, without recurrence.

\section{Case 4}

A 37-year-old man presented to our emergency department with upper abdominal colicky pain. He had eaten a boiled rice cake without chewing well the day before. His vital signs, physical examination findings, and laboratory 


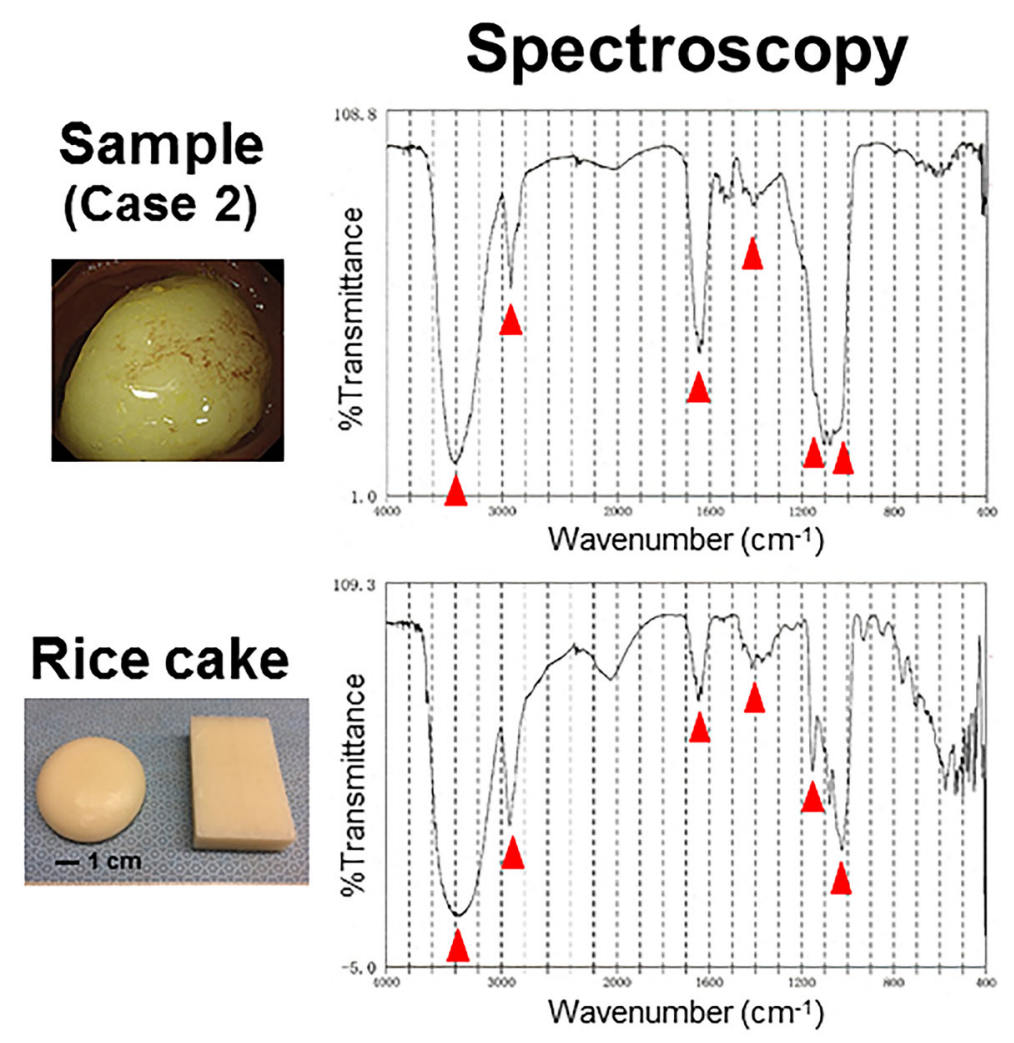

Figure 4. Infrared spectroscopy images. Infrared spectroscopy of the foreign body from Case 2 (upper panel) showing spectra lower than $800 \mathrm{~cm}^{-1}$ appearing similar to those of commercially obtained rice cake (lower panel, size of left rice cake: $5 \times 4.8 \times 1.5 \mathrm{~cm}$, right: $6 \times 3.8 \times 1.5 \mathrm{~cm}$ ). Black bar indicates $1 \mathrm{~cm}$.

tests were within normal limits. Sonography showed a $2-\mathrm{cm}$ hyperechoic, arc-like echo with acoustic shadowing in the gastric antrum (Fig. 6A). CT revealed a $2.0 \times 1.5-\mathrm{cm}$ highdensity (122 HU) foreign body in the gastric antrum (Fig. 6B). Endoscopy did not detect the foreign body but did reveal multiple circular erosions on the pyloric ring (Fig. 6C). Based on these CT and endoscopic findings and his food-intake history, we diagnosed the findings as a foreign body consisting of retained rice cake passing spontaneously through the pyloric ring. The patient's pain rapidly disappeared after endoscopy. The erosions were successfully treated with rabeprazole, without recurrence. At the time of this writing, the patient has remained free from complications, such as small bowel obstruction/perforation and GI bleeding.

\section{Case 5 [adapted from our previously published Japanese report (10)]}

A 76-year-old man presented to our gastroenterology department with upper abdominal colicky pain and vomiting. He had eaten boiled rice cakes without chewing well because of his dentures six days previously. A physical examination revealed a mildly tender upper abdomen. CT showed multiple high-density objects $(2.0,1.8$, and $1.5 \mathrm{~cm} ; 137,142$ and $152 \mathrm{HU}$, respectively, Fig. 7A) in the stomach, small intestine, and colon, respectively. Endoscopy revealed multiple ulcers located in the gastric antrum and body of the stomach and that the rice cake had passed spontaneously (Fig. 7B). The ulcers were successfully treated with lansoprazole with no recurrence.

\section{Case 6 [adapted from our published Japanese re- port (10)]}

An 85-year-old man presented to our gastroenterology department with upper abdominal colicky pain. He had eaten boiled rice cakes without chewing well because of his dentures one day before. A physical examination revealed a mildly tender upper abdomen. CT revealed a high-density (136 HU) object obstructing the small intestine on day 1 (Fig. 7C), and on day 3 after bowel rest, CT revealed spontaneous passage of the object. Endoscopy on day 5 revealed multiple ulcers and erosions in the gastric antrum (Fig. 7D), representing rice cake-related lesions. The gastric ulcers were successfully treated with rabeprazole without recurrence.

\section{Discussion}

Rice cake as a foreign body (retained rice cake) in the stomach is rare; we searched two databases-the PubMed and Japan Medical Abstracts Society databases (Ichushi Web)using the following keywords: "stomach", "rice cake", "foreign body", "erosion" and "ulcer" and found nine cases published between 1977 and 2018 (Table 1). All of the re- 

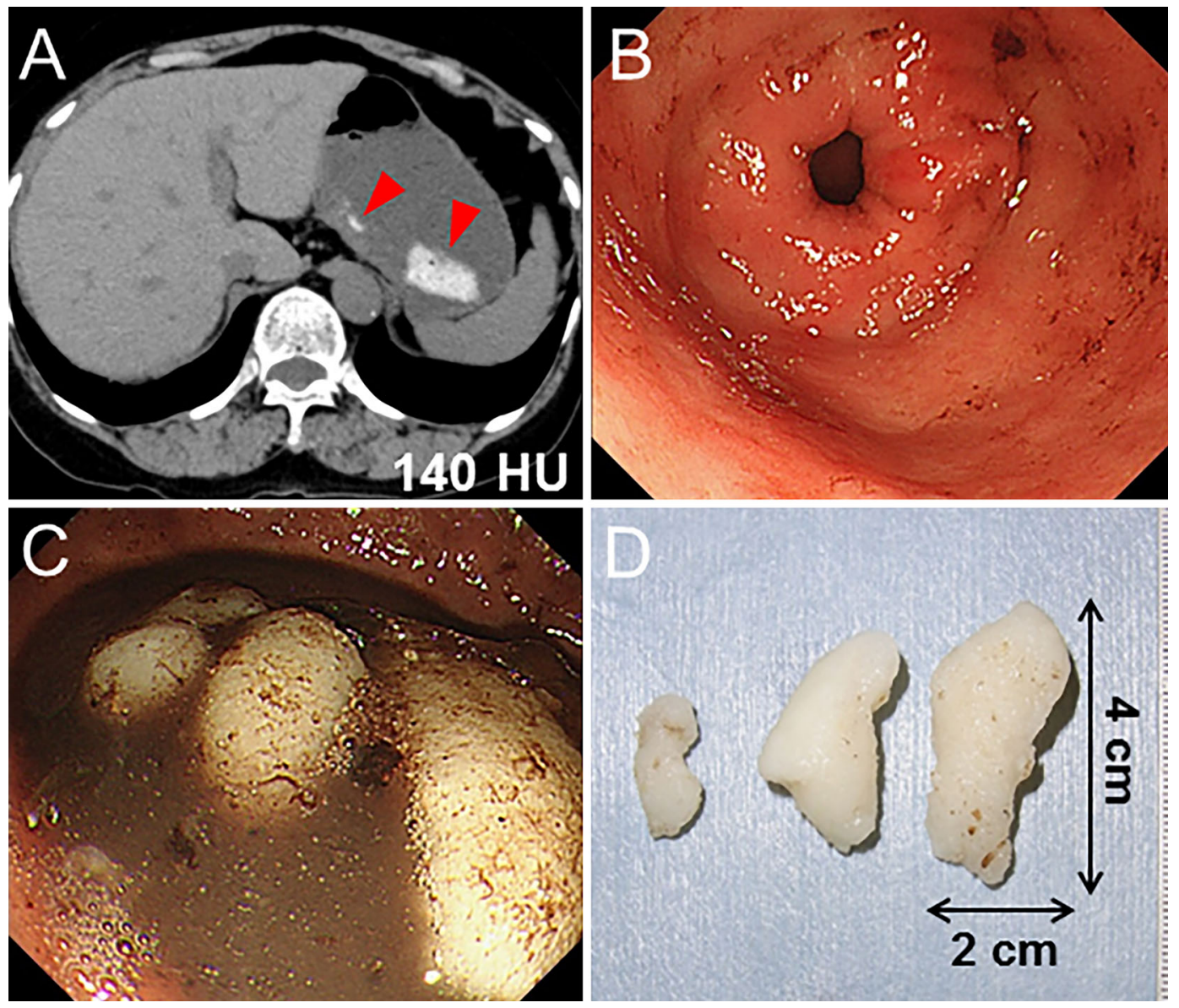

Figure 5. Computed tomography (CT) and endoscopy images from Case 3 (70-year-old woman). (A) Plain CT image showing high-density objects (red arrowheads) in the stomach. CT number=140 HU (window width: 30; window level: 300; region of interest: $20 \mathrm{~mm}^{2}$ ). (B) Endoscopy image revealing erosions in the gastric antrum. (C) Endoscopy image demonstrating retained rice cakes (white objects) with coffee-colored bloody fluid in the fornix. (D) Picture showing rice cakes removed with an endoscopic net (Olympus-00711180).

ported cases were from Japan; however, given that Asian cuisine is one of the most popular in the world (14), rice cake-related disorders are expected to occur worldwide. According to our review, intragastric retained rice cake occurred mostly in elderly people (mean age 62.6 years, range 30-94 years) and mainly in men (men:women $=11: 4$ ). The major symptom was colicky abdominal pain (93.3\%), reflecting obstruction of the gastric outlet by retained rice cake. Minor signs and symptoms were nausea/vomiting (26.7\%) and appetite loss (6.7\%).

Common complications of intragastric retained rice cake were mucosal injury (erosion or ulcer) $(93.3 \%)$ with bleeding $(42.9 \%$ in mucosal injury cases) (Table 1). This high rate of mucosal injury, compared to that with bezoarinduced injury $(41.2-52.9 \%)(15,16)$, is likely due to the stickiness and hardness of the retained rice cake. In fact, one hard, retained rice cake deformed the shape of our endoscopic snare during excision. The mechanism underlying mucosal injury associated with a hard retained rice cake has been presumed to be similar to that involved in the development of a bezoar-related ulcer, namely mechanical compres- sion $(11,12,17)$. We confirmed this assumption by a histological analysis, which showed mucosal ischemia [edematous stromal tissue and diffuse loss of epithelium (ghost-like appearance)] compatible with a compression injury associated with a hard material (Fig. 2F, 3D). The endoscopic characteristics of rice cake-induced mucosal injury seem to be "multiple" "circular lesions" on the pyloric ring in the "antrum" (92.9\%).

The retainment of a rice cake is likely due to the following: 1) its unique physical property and 2) patient-related factors. An uncooked hard rice cake becomes "soft" and "sticky" after being cooked (toasted or boiled), enabling people who have ingestion-related problems such as dentures $(40 \%)$, rapid eating $(13.3 \%)$, and tooth loss $(6.7 \%)$ to swallow large pieces of rice cake without chewing well, and commercial rice cakes are large (normally greater than $5 \mathrm{~cm}$ in diameter, Fig. 4). Once at body temperature, large pieces of ingested soft rice cake become hard again (10), which leads to retainment; materials larger than $2 \mathrm{~cm}$ in any dimension tend to result in obstruction of the stomach or duodenum $(6,18)$. Indeed, in our review, the diameters of the 


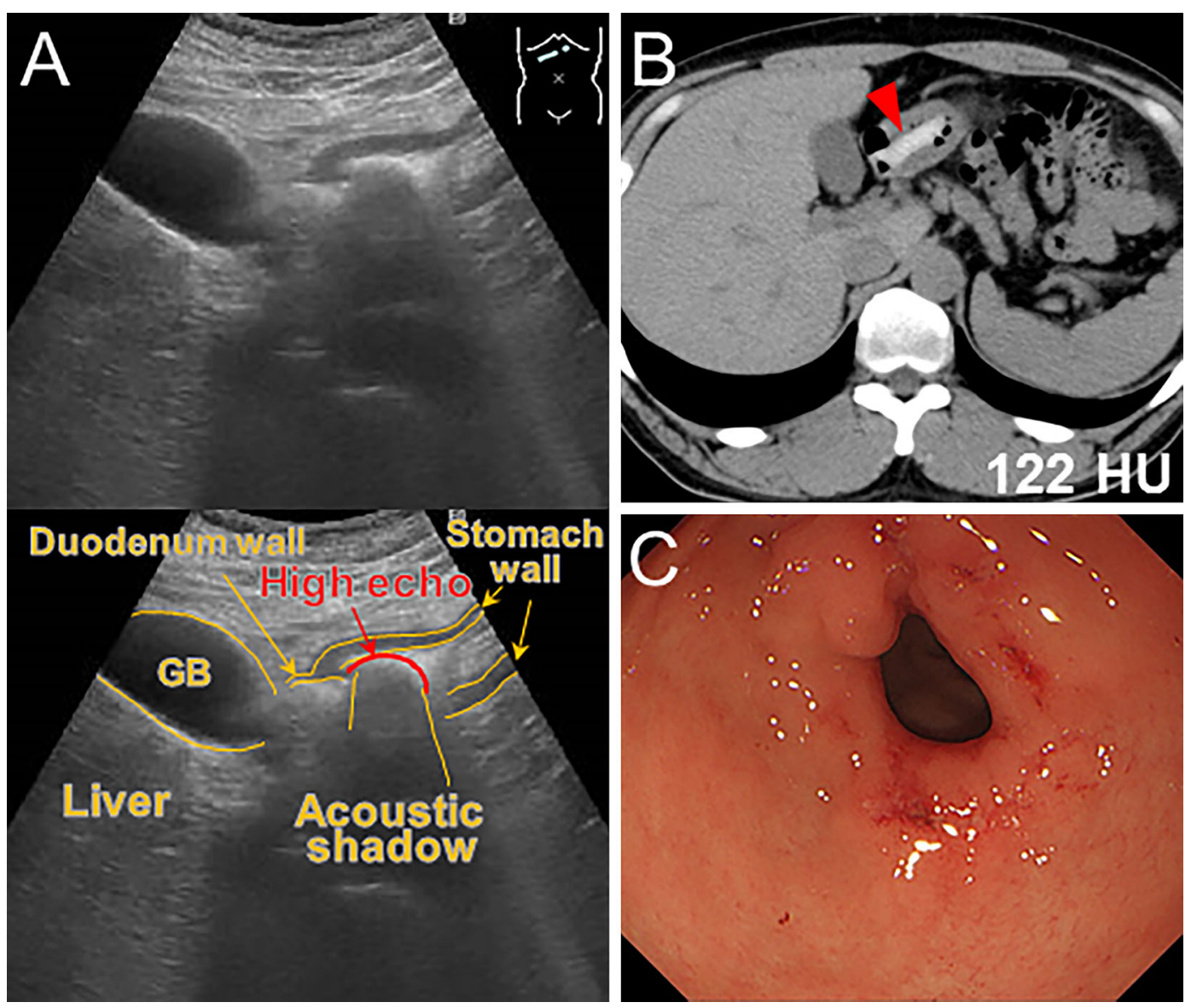

Figure 6. Sonography, computed tomography (CT), and endoscopy images from Case 4 (37-yearold man). (A) Upper abdominal sonogram showing hyperechoic arc-like echo with acoustic shadowing in the gastric antrum. GB: gall bladder. (B) Plain CT image demonstrating rice cake as a highdensity object (red arrowheads) in the stomach. CT number=122 HU (window width: 30; window level: 300; region of interest: $20 \mathrm{~mm}^{2}$ ). (C) Endoscopy image showing round erosions on the pyloric ring.

retained pieces of rice cake were $\geq 2 \mathrm{~cm}$ (Table 1 ).

$\mathrm{CT}$ is the first-line imaging method for the diagnosis of retained rice cake (performed in $80 \%$ of cases, Table 1) $(7,10)$, clearly demonstrating high-density objects. Furthermore, the CT number is very useful for distinguishing rice cake from other foods (Fig. 8) (7, 10). However, sonography has been shown to be useful for revealing the cause of acute abdomen and intestinal obstruction (19). We detected rice cake as a hyperechoic material with strong acoustic shadowing, indicating a hard object. Although sonography cannot easily identify the type of foreign body (10), sonography has advantages in that it can safely and rapidly detect a foreign body and its location in the GI tract by scanning the area of tenderness on the patient.

Endoscopic treatments for retained rice cake were performed in $80 \%$ of cases $(12 / 15)$ (Table 1) $(1,6)$. In 2 cases $(13.3 \%)$, retained rice cakes spontaneously passed without any complications. In 1 case $(6.7 \%)$, the rice cake exited the stomach but obstructed the small intestine. Objects $\geq 2 \mathrm{~cm}$ in size can cause obstruction of the stomach, duodenum $(1,6,18)$ and small intestine (10). In addition, retained rice cake occasionally remains in the GI tract for up to 3 months (20), as cooked rice cake contains higher concentrations of digestion-resistant starch than raw rice (21). Therefore, retained rice cake pieces $\geq 2 \mathrm{~cm}$ should be considered for excision and removal from the upper GI tract. A common excision procedure uses a snare without electrical current (cold snaring), and the removal procedure involves capturing the object with a net or basket snare. To identify rice cake, infrared spectroscopy is useful, and this approach is usually used to identify types of gallstones and choledocholiths; this technique has been shown to be useful for the diagnosis of types of bezoars $(22,23)$. In our Case 2, the fingerprint region of starch (spectra lower than $800 \mathrm{~cm}^{-1}$ ) helped identify the object as a rice cake (Fig. 4) (24).

The mucosal injury due to retained rice cake is reversible and not serious; most cases were successfully treated with conservative treatment, such as a histamine receptor type 2 (H2) blocker and proton pump inhibitor.

In addition to the cases of retained rice cake in the stomach, we found cases involving the esophagus and duodenum in the Ichushi Web database (Table 2). Similar clinical fea- 

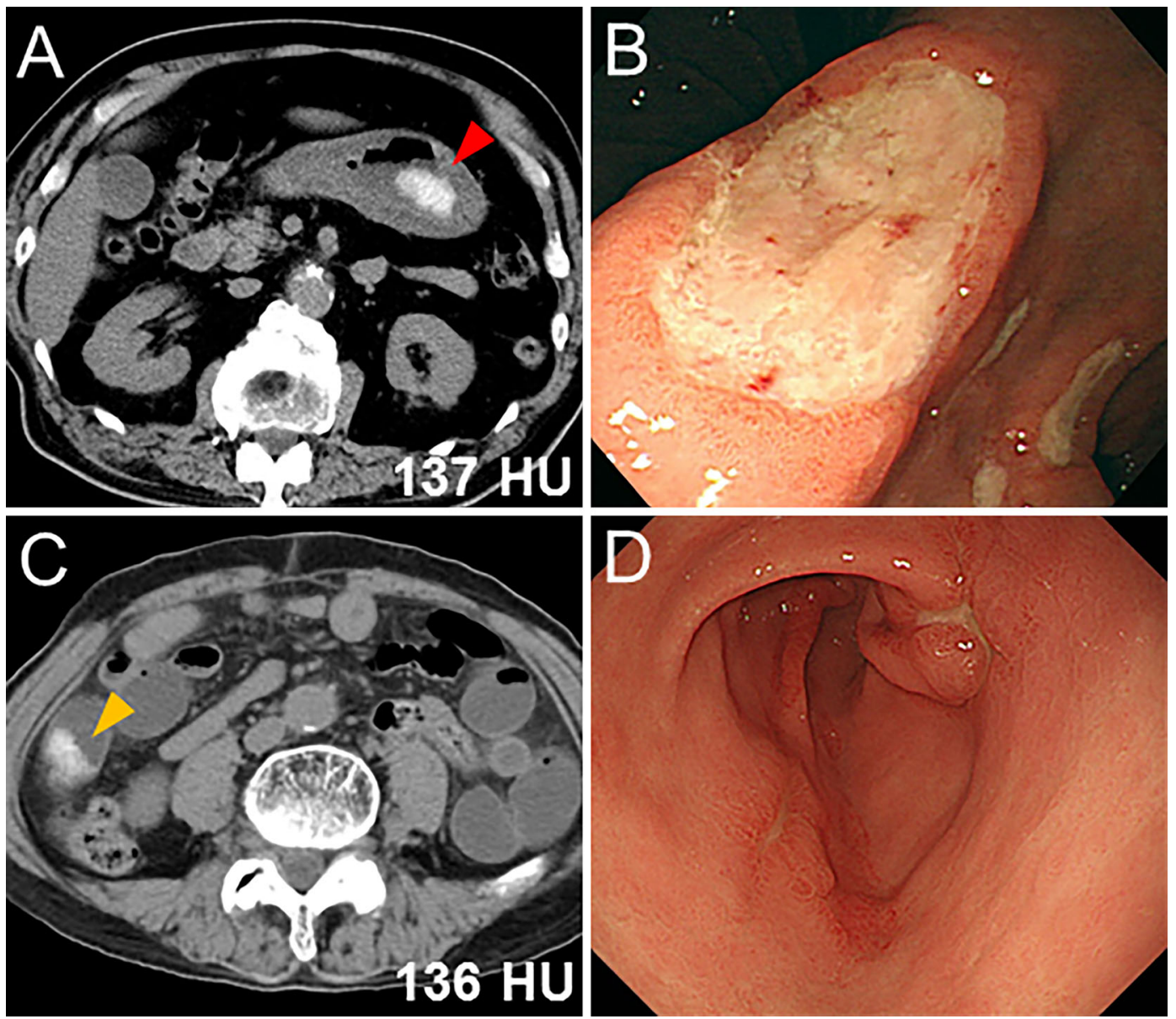

Figure 7. Endoscopy images from Case 5 (76-year-old man) and Case 6 (85-year-old man). (A) Plain CT image demonstrating rice cake as a high-density object (red arrowhead) in the stomach of Case 5. CT number=137 HU (window width: 30; window level: 300; region of interest: $20 \mathrm{~mm}^{2}$ ). (B) Endoscopy image showing multiple ulcers in the gastric antrum and body of Case 5. (C) Plain CT image demonstrating the rice cake as a high-density object (yellow arrowhead) in the small intestine of Case 6. CT number=136 HU (window width: 30; window level: 300; region of interest: $20 \mathrm{~mm}^{2}$ ). (D) Endoscopy image showing multiple ulcers in the gastric antrum of Case 6.

tures were found for the cases involving the duodenum, whereas the cases involving the esophagus showed very different features. Almost all cases involving the esophagus showed acute thermal injury caused by hot, toasted rice cakes. Lim et al. (25) recently reviewed cases of esophageal thermal injury and reported that 18 cases were published in English from 1982 to 2015; the common causes were hot drinks (tea and soup) and foods (hamburger and dumpling). Rice cakes have not yet been reported in the English literature. According our review, the age of patients in rice cakerelated esophageal cases was younger than in patients in rice cake-related stomach/duodenum cases (median age 41.5 vs. 63.0 years old, $\mathrm{p}=0.0548$, Mann Whitney 2-tailed test). While the precise reason for this age difference is unclear, eating habits (hot or cold, etc.) and age-related impaired ingestion (loss of teeth, presence of dentures, etc.) might be involved.

The treatment of esophageal thermal injury is conservative and includes observation and antiulcer agents (Table 2) (25). Retainment of rice cake occurred in only 1 case and was treated by enzyme therapy (a mixed digestant containing pancreatin, biodiastase, lipase, and cellulase), which quickly dissolved the rice cake that had been retained for 15 days. Since an endoscopic procedure is sometimes difficult and dangerous to perform in a narrow space such as the esophagus or duodenum, enzyme therapy can be considered as an alternative therapy.

In conclusion, retained rice cake frequently requires an endoscopic procedure for resolution. Therefore, primary care physicians and emergency doctors, as well as gastroenterologists, should become familiar with the clinical features of and therapeutic methods for this rare but popular-foodrelated foreign body.

The authors state that they have no Conflict of Interest (COI).

\section{Acknowledgement}

We wish to thank Drs. N. Ishikawa, C. Amano, and R. Maruyama (Department of Pathology, Shimane University, School of Medicine, Izumo, Shimane, Japan) for histological 
Table 1. Rice-cake-related Upper Gastrointestinal Disorders (stomach) (1977-2018).

\begin{tabular}{|c|c|c|c|c|c|c|c|c|}
\hline \multirow[b]{2}{*}{ Reference } & \multirow{2}{*}{$\begin{array}{l}\text { Age }(\mathrm{yr}) / \\
\text { gender }\end{array}$} & \multicolumn{2}{|c|}{ Rice cake } & \multirow[b]{2}{*}{ Symptoms } & \multirow[b]{2}{*}{ Diagnosis } & \multirow{2}{*}{$\begin{array}{l}\text { Loca- } \\
\text { tion of } \\
\text { disorder }\end{array}$} & \multirow{2}{*}{$\begin{array}{l}\text { Duration of } \\
\text { retainment } \\
\text { of rice cake }\end{array}$} & \multirow[b]{2}{*}{ Therapies } \\
\hline & & $\begin{array}{l}\mathrm{CT} \# \\
\text { (HU) }\end{array}$ & $\begin{array}{l}\text { Size } \\
(\mathrm{cm})\end{array}$ & & & & & \\
\hline \multicolumn{9}{|c|}{ Stomach (15 cases) } \\
\hline (26) & $45 / \mathrm{M}$ & & & Abd. pain & $\begin{array}{l}\text { AGML with } \\
\text { blood }\end{array}$ & Antrum & $1 \mathrm{wk}$ & $\begin{array}{l}\text { Endoscopy, } \\
\text { H2-blocker }\end{array}$ \\
\hline (27) & $59 / \mathrm{M}$ & & 4 & Abd. pain & Ulcers & Antrum & $4 \mathrm{~d}$ & $\begin{array}{c}\text { Endoscopy (snare), } \\
\text { H2-blocker }\end{array}$ \\
\hline (28) & $30 / \mathrm{M}$ & High & & Abd. pain & $\begin{array}{l}\text { Erosions, } \\
\text { obstruction }\end{array}$ & Antrum & & Endoscopy (net) \\
\hline (29) & $67 / \mathrm{M}$ & High & 4 & $\begin{array}{l}\text { Abd. pain, } \\
\text { melena }\end{array}$ & Ulcers & Antrum & $5 \mathrm{~d}$ & Endoscopy (snare) \\
\hline (11) & $67 / M$ & High & 4 & $\begin{array}{l}\text { Abd. pain, } \\
\text { melena }\end{array}$ & $\begin{array}{c}\text { Ulcers, } \\
\text { obstruction }\end{array}$ & Antrum & $5 \mathrm{~d}$ & Endoscopy (snare) \\
\hline (30) & $59 / \mathrm{M}$ & High & $>4$ & Abd. pain & $\begin{array}{l}\text { Foreign } \\
\text { bodies }\end{array}$ & & $1 \mathrm{~d}$ & Endoscopy (snare) \\
\hline (30) & $94 / \mathrm{F}$ & High & $>4$ & $\begin{array}{l}\text { Appetite } \\
\text { loss }\end{array}$ & $\begin{array}{l}\text { Ulcers with } \\
\text { blood, } \\
\text { anemia }\end{array}$ & Entire & several d & $\begin{array}{l}\text { Endoscopy (snare), } \\
\text { anti-ulcer agent }\end{array}$ \\
\hline (31) & $63 / \mathrm{M}$ & High & & $\begin{array}{l}\text { Abd. pain, } \\
\text { nausea }\end{array}$ & $\begin{array}{l}\text { Obstruction, } \\
\text { ulcers }\end{array}$ & Antrum & $>2 \mathrm{~d}$ & $\begin{array}{c}\text { Endoscopy (snare), } \\
\text { anti-acid agent }\end{array}$ \\
\hline (12) & $60 / \mathrm{M}$ & High & 3 & $\begin{array}{l}\text { Abd. pain, } \\
\text { melena }\end{array}$ & Ulcer & Antrum & $1 \mathrm{mo}$ & Endoscopy (snare) \\
\hline Case 1 & $68 / \mathrm{F}$ & 192 & 4.7 & $\begin{array}{l}\text { Abd. pain, } \\
\text { vomiting }\end{array}$ & Erosions & Antrum & $1 / 2 \mathrm{~d}$ & $\begin{array}{c}\text { Endoscopy (snare, } \\
\text { net), PPI }\end{array}$ \\
\hline Case 2 & $59 / \mathrm{F}$ & & 2 & Abd. pain & Erosions & Antrum & $1 / 2 \mathrm{~d}$ & $\begin{array}{c}\text { Endoscopy (net), } \\
\text { PPI }\end{array}$ \\
\hline Case 3 & $70 / \mathrm{F}$ & 140 & 3.5 & $\begin{array}{l}\text { Abd. pain, } \\
\text { vomiting }\end{array}$ & $\begin{array}{l}\text { Erosions } \\
\text { with blood }\end{array}$ & Antrum & $1 / 2 \mathrm{~d}$ & $\begin{array}{c}\text { Endoscopy (net), } \\
\text { PPI }\end{array}$ \\
\hline Case 4 & $37 / \mathrm{M}$ & 122 & 2 & Abd. pain & Erosions & Antrum & $1 \mathrm{~d}$ & Conservative (PPI) \\
\hline $\begin{array}{c}\text { Case } 5 \\
(10)\end{array}$ & $76 / \mathrm{M}$ & 137 & 2 & $\begin{array}{l}\text { Abd. pain, } \\
\text { vomiting }\end{array}$ & Ulcers & $\begin{array}{l}\text { Antrum, } \\
\text { body }\end{array}$ & $6 \mathrm{~d}$ & Conservative (PPI) \\
\hline $\begin{array}{l}\text { Case } 6 \\
(10)\end{array}$ & $85 / \mathrm{M}$ & 136 & & Abd. pain & Ulcers & Antrum & & Conservative (PPI) \\
\hline
\end{tabular}

CT: computed tomography, HU: Hounsfield units, M: male, F: female, Abd.: abdominal, wk: week, d: day, mo: month, AGML: acute gastric mucosal lesion, H2-blocker: histamine receptor type 2 inhibitor, PPI: proton pump inhibitor

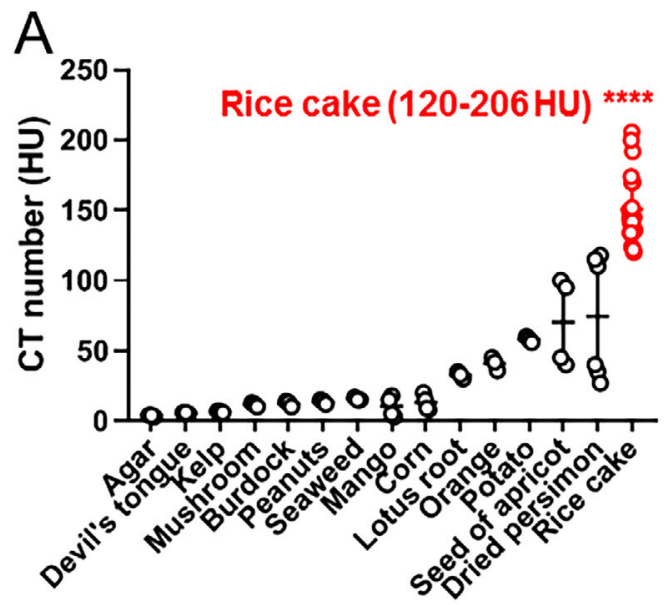

B

\begin{tabular}{|c|c|c|c|c|}
\hline \multirow{2}{*}{ Food } & \multicolumn{3}{|c|}{ CT number (HU) } & \multirow{2}{*}{$\begin{array}{c}\text { P value } \\
\text { (v.s. rice cake) }\end{array}$} \\
\hline & Max-Min & Mean & $+/-S D$ & \\
\hline Rice cake & $206-120$ & 150.7 & 25.1 & \\
\hline Dried persimmon & $118-27$ & 74.2 & 44.3 & $<0.0001$ \\
\hline Seed of apricot & $100-40$ & 70.0 & 31.9 & $<0.0001$ \\
\hline Potato & 60.56 & 58.0 & 2.0 & $<0.0001$ \\
\hline Orange & $45-36$ & 41.0 & 4.6 & $<0.0001$ \\
\hline Lotus root & $35-30$ & 32.7 & 2.5 & $<0.0001$ \\
\hline Com & $20-8$ & 13.0 & 5.6 & $<0.0001$ \\
\hline Mango & $18-3$ & 10.3 & 7.4 & $<0.0001$ \\
\hline Seaweed & $17-15$ & 15.7 & 1.2 & $<0.0001$ \\
\hline Peanuts & $15-12$ & 13.7 & 1.5 & $<0.0001$ \\
\hline Burdod & $14-10$ & 12.3 & 2.1 & $<0.0001$ \\
\hline Mushroom & $13-10$ & 11.7 & 1.5 & $<0.0001$ \\
\hline Kelp & $7-6$ & 6.7 & 0.6 & $<0.0001$ \\
\hline Devirs tongue & 6.5 & 5.7 & 0.6 & $<0.0001$ \\
\hline Agar & $4-3$ & 3.7 & 0.6 & $<0.0001$ \\
\hline
\end{tabular}

Figure 8. CT numbers of foods. (A) Scatter plots (bar indicates the mean \pm SD). ****, p values are shown in panel $B$ (each point represents a case). Data of other foods are taken from the database of our previous review (10) (each point represents replications, 3-6 replications/food). (B) Table of detailed data on CT numbers of indicated foods. Data on rice cakes are from this case series, reference (7), and our previous review (10). Window width: 30; window level: 300; region of interest: $20 \mathrm{~mm}^{2}$. The p value was analyzed by Dunnett's multiple comparisons test. 
Table 2. Rice-cake-related Upper Gastrointestinal Disorders (Esophagus and Duodenum) (1977-2018)

\begin{tabular}{|c|c|c|c|c|c|c|c|c|}
\hline \multirow[b]{2}{*}{ Reference } & \multirow[b]{2}{*}{$\begin{array}{l}\text { Age }(y r) / \\
\text { gender }\end{array}$} & \multicolumn{2}{|c|}{ Rice cake } & \multirow[b]{2}{*}{ Symptoms } & \multirow[b]{2}{*}{ Diagnosis } & \multirow{2}{*}{$\begin{array}{l}\text { Location } \\
\text { of } \\
\text { disorder }\end{array}$} & \multirow{2}{*}{$\begin{array}{l}\text { Duration of } \\
\text { retainment } \\
\text { of rice cake }\end{array}$} & \multirow[b]{2}{*}{ Therapies } \\
\hline & & $\begin{array}{l}\text { CT \# } \\
(\mathrm{HU})\end{array}$ & $\begin{array}{l}\text { Size } \\
(\mathrm{cm})\end{array}$ & & & & & \\
\hline $\begin{array}{l}\text { Esophagus } \\
\text { ( } 8 \text { cases })\end{array}$ & & & & & & $\begin{array}{l}\text { (from } \\
\text { incisors) }\end{array}$ & & \\
\hline (32) & $40 / \mathrm{F}$ & & & Chest pain & $\begin{array}{c}\text { Ulcers } \\
\text { (thermal injury) }\end{array}$ & $25 \mathrm{~cm}$ & & Conservative \\
\hline (33) & 29/M & & & Vomiting & Erosion & & & Conservative \\
\hline (34) & $43 / \mathrm{F}$ & & & $\begin{array}{c}\text { Dysphagia, } \\
\text { bloody } \\
\text { vomiting }\end{array}$ & Erosions & Entire & & Conservative \\
\hline (35) & $33 / \mathrm{F}$ & & & $\begin{array}{c}\text { Chest pain, } \\
\text { dysphagia }\end{array}$ & $\begin{array}{c}\text { Ulcers } \\
\text { (thermal injury) }\end{array}$ & $30 \mathrm{~cm}$ & & Conservative \\
\hline (36) & $70 / \mathrm{F}$ & & & $\begin{array}{c}\text { Painful } \\
\text { swallowing }\end{array}$ & $\begin{array}{c}\text { Ulcer } \\
\text { (thermal injury) }\end{array}$ & $24 \mathrm{~cm}$ & & $\begin{array}{c}\text { Conservative } \\
\text { (anti-ulcer agent) }\end{array}$ \\
\hline (37) & $26 / \mathrm{M}$ & & & $\begin{array}{c}\text { Chest pain, } \\
\text { vomiting }\end{array}$ & $\begin{array}{c}\text { Erosions } \\
\text { (thermal injury) }\end{array}$ & $30 \mathrm{~cm}$ & & Conservative \\
\hline (38) & $47 / \mathrm{F}$ & & & $\begin{array}{c}\text { Painful } \\
\text { swallowing }\end{array}$ & $\begin{array}{c}\text { Erosion } \\
\text { (thermal injury) }\end{array}$ & $28-30 \mathrm{~cm}$ & & $\begin{array}{c}\text { Conservative } \\
\text { (anti-ulcer agent) }\end{array}$ \\
\hline (39) & $82 / \mathrm{M}$ & & & $\begin{array}{l}\text { Dysphagia, } \\
\text { vomiting }\end{array}$ & $\begin{array}{l}\text { Obstruction, } \\
\text { pneumonia }\end{array}$ & $32 \mathrm{~cm}$ & $15 \mathrm{~d}$ & $\begin{array}{l}\text { Conservative } \\
\text { (digestant) }\end{array}$ \\
\hline \multicolumn{9}{|l|}{$\begin{array}{l}\text { Duodenum } \\
\text { ( } 2 \text { cases) }\end{array}$} \\
\hline (40) & 89/NA & & & & $\begin{array}{l}\text { Obstruction, } \\
\text { ulcer }\end{array}$ & Bulb & & $\begin{array}{l}\text { Endoscopy } \\
\text { (basket) }\end{array}$ \\
\hline (41) & $47 / \mathrm{M}$ & High & & $\begin{array}{l}\text { Abd. pain, } \\
\text { bloody } \\
\text { vomiting }\end{array}$ & Obstruction & Bulb & $1 \mathrm{~d}$ & $\begin{array}{l}\text { Endoscopy } \\
\text { (basket) }\end{array}$ \\
\hline
\end{tabular}

CT: computed tomography, HU: Hounsfield units, M: male, F: female, NA: not available, Abd.: abdominal, d: day

processing of specimens and assessments.

\section{References}

1. Pfau P. Ingested foreign objects and food bolus impactions. In: Clinical Gastrointestinal Endoscopy. Ginsberg G, Kochman M, Norton I, et al., Eds. Elsevier Saunders, Philadelphia, 2005: 291303.

2. Eisen GM, Baron TH, Dominitz JA, et al. Guideline for the management of ingested foreign bodies. Gastrointest Endosc 55: 802806, 2002.

3. Webb WA. Management of foreign bodies of the upper gastrointestinal tract: update. Gastrointest Endosc 41: 39-51, 1995.

4. Weinstock LB, Shatz BA, Thyssen SE. Esophageal food bolus obstruction: evaluation of extraction and modified push techniques in 75 cases. Endoscopy 31: 421-425, 1999.

5. Vizcarrondo FJ, Brady PG, Nord HJ. Foreign bodies of the upper gastrointestinal tract. Gastrointest Endosc 29: 208-210, 1983.

6. Rabine JC, Nostrant TT. Miscellaneous diseases of the stomach. In: Textbook of Gastroenterology. 4th ed. Yamada T, Alpers DH, Kaploqitz N, et al., Eds. Lippincott. Williams and Wilkins, Philadelphia, 2003: 1455-1465.

7. Usui A, Kawasumi Y, Hosokai Y, et al. Postmortem computed tomography suggests the possibility of fatal asphyxiation by mochi, Japanese rice cakes: a case report of postmortem radiologic findings. J Forensic Radiol Imaging 6: 42-45, 2016.

8. Sekiguchi T. Mochi: New Year's Silent Killer. The Wall Street Journal [Internet]. [cited 2011 Jan 4]. Available from https://blogs. wsj.com/japanrealtime/2011/01/04/mochi-new-years-silent-killer/

9. Miura T, Kimura N, Nakamura J, et al. Rice cake ileus - a rare and ethnic but important disease status in east-southern Asia. In- tern Med 50: 2737-2739, 2011.

10. Oka A, Amano Y, Uchida Y, et al. Small bowel obstruction and gastric ulceration resulting from rice cake ingestion -computed tomography diagnosis in eight patients-. Nihon Shokakibyo Gakkai Zasshi (Japanese J Gastroenterol) 110: 1804-1813, 2013 (in Japanese, Abstract in English).

11. Fujii M, Sakashita K, Wakamura K, et al. Multiple gastric ulcers caused by a rice cake as an intragastric foreign body. J Gastroenterol 41: 282-283, 2006

12. Kiyotoki S, Nishikawa J, Tajima K, Sakaida I. Gastric ulcer caused by the retention of rice cakes. Intern Med 54: 241-242, 2015.

13. Dragunski DC, Pawlicka A. Preparation and characterization of starch grafted with toluene poly (propylene oxide) diisocyanate. Mater Res 4: 77-81, 2001.

14. Ferdman RA. Asian food: the fastest growing food in the world. The Washington Post. [Internet]. 2015 [cited 2015 Feb 3]. Available at https://www.washingtonpost.com/news/wonk/wp/2015/02/0 $3 /$ the-fastest-growing-food-in-the-world/?noredirect=on \&utm_term $=.8 \mathrm{a} 59826 \mathrm{de} 371$

15. Iwamuro M, Tanaka S, Shiode J, et al. Clinical characteristics and treatment outcomes of nineteen Japanese patients with gastrointestinal bezoars. Intern Med 53: 1099-1105, 2014.

16. Lee BJ, Park JJ, Chun HJ, et al. How good is cola for dissolution of gastric phytobezoars? World J Gastroenterol 15: 2265-2269, 2009.

17. Sanders MK. Bezoars: from mystical charms to medical and nutritional management. Practical Gastroenteroly XXVIII: 37-50, 2004.

18. Soergel KH, Hogan WJ. Therapeutic endoscopy. Hosp Pract (Off Ed) 18: 81-92, 1983 . 
19. Lim JH. Intestinal obstruction. In: Ultrasound of the Gastrointestinal Tract. Maconi G, Bianchi Porro G, Eds. Springer Berlin Heidelberg, Berlin Heidelberg, 2007: 27-34.

20. Yamamoto H, Nara S, Hida K, Yamamoto E, Konishi H, Takeda A. A case of alimentary ileus-like condition due to "mochi" persisted for 3 months with resultant perforation of the small intestine causing generalized peritonitis. Nihon Rinsho Geka Gakkai Zasshi (J Jpn Surg Assoc) 64: 370-374, 2003 (in Japanese, Abstract in English).

21. Juliano BO, Hicks PA. Rice functional properties and rice food products. Food Rev Int 12: 71-103, 1996

22. Oka A, Ishihara $S$, Kinoshita $Y$. An unusual case of a gastric foreign body. Gastroenterology 145: 1206, 1500-1501, 2013.

23. Bergstrom TC, Sakai RR, Nieto JE. Catastrophic gastric rupture in a horse secondary to psyllium pharmacobezoars. La revue veterinaire canadienne (Can Vet J) 59: 249-253, 2018.

24. Huang CB, Jeng R, Sain M, Saville BA, Hubbes M. Production, characterization, and mechanical properties of starch modified by Ophiostoma Spp. BioResources 1: 257-269, 2006.

25. Lim CH, Yen HH, Su WW, Lim CJ, Tsai HC, Chen ST. Extensive causative esophagitis caused by thermal injury: a case report and review of the literature. Case Rep Gastrointest Med 2017: 1-7, 2017.

26. Azai S, Tsukamoto T, Nomura Y, Himuro M, Inamoto Y. Acute gastric mucosal lesion due to rice cake. Shoukaki Naishikyou (Endoscopia Digestiva) 7: 1774-1775, 1995 (in Japanese).

27. Hosoda A, Kitamura A, Shiota G, et al. A case report on rice cakes as an intragastric foreign body broken by endoscopic treatment. Shoukaki Naishikyou (Endoscopia Digestiva) 15: 119-123, 2003 (in Japanese, Abstract in English).

28. Ibuki S, Kobayashi H, Ishito H, Ae T, Maruyama T, Murabayashi K. A case report on severe upper abdominal pain due to pyloric obstruction by rice cake. Shoukaki Naishikyou No Shinpo (Prog Dig Endosc) 67: 67, 2005 (in Japanese).

29. Horimatsu T, Sakashita M, Fujii M, et al. Two cases of acute abdomen due to food-related foreign body (rice cake). Nihon Shoukaki Naishikyou Gakkai Zasshi (Gastroenterol Endosc) 47: 842, 2005 (in Japanese).

30. Horie S, Sawada S, Ayaki M, Kashiwagi R, Mitsuda A, Tanaka H. Two cases of retained rice cakes in the stomach, successfully removed by endoscope. Tottori Sekijuji Byouin Igaku Zasshi (Medical Journal of Tottori Red Cross Hospital) 20: 16-19, 2011 (in Japanese).

31. Tsuchida T, Baba S, Kushige N, Komiyama A. A case reports on severe upper abdominal pain due to obstruction of gastric pylorus by rice cake. Nihon Naika Gakkai Zasshi (Journal of Japanese Society of Internal Medicine) 581: 24, 2011 (in Japanese).

32. Shimaguchi S, Minami K, Kouyama K, Ishikoshi K, Nakayama R. Three cases of acute esophageal ulcer. Nihon Shoukaki Naishikyou Gakkai Zasshi (Gastroenterol Endosc) 19: 455, 1977 (in Japanese).

33. Kazusa S, Mizuochi K, Kohda S, et al. Two cases of esophageal injury with hematemesis caused by hard material. Shoukaki Naishikyou No Shinpo (Prog Dig Endosc) 21: 135-138, 1982 (in Japanease).

34. Shinoda T, Fukurake K, Kawamorita Y, et al. Two cases of esophageal submucosal dissection. Shoukaki Naishikyou No Shinpo (Prog Dig Endosc) 24: 192-194, 1984 (in Japanease, Abstract in English).

35. Matsuo S, Imaoka T, Nishikori $Y$, et al. A report of two cases of esophageal ulcer due to thermal burn and clinical studies on mechanism of occurrence of esophageal ulcer. Shimane Kenritsu Chuou Byouin Igaku Zasshi (Med J Shimane Pref Cent Hosp) 12: 30, 1985 (in Japanese).

36. Kuriyama A. A case of esophageal ulcer caused by burn. Endoscopic forum for digestive disease 5: 61-63, 1989 (in Japanese, Abstract in English).

37. Ichioka S, Fujibayashi M, Hirai M, Seki Y, Hoshino S, Matsuo S. Thermal esophagitis caused by ingested food. Rinshou Shoukakinaika (Clinical Gastroenterology) 4: 461-464, 1989 (in Japanese).

38. Mutsukura T, Ogawa Y. A case of esophageal thermal injury caused by toasted rice cake. Kanagawa Igakkai Zasshi (Kanagawa Med Ass) 23: 118, 1996 (in Japanese).

39. Ichii $\mathrm{O}$, Ono H, Saito T, et al. A case of esophageal obstruction by rice cake, successfully recovered with Berizym. Shoukaki Naishikyou No Shinpo (Prog Dig Endosc) 59: 95, 2001 (in Japanese).

40. Iwai N, Doumae T, Watanabe K, Iwai H. A case report of duodenal ulcer in elderly patient with rice cake obstruction. Fukuiken Igakkai Zasshi (Fukui Medical Journal) 7: 202, 1994 (in Japanese).

41. Sugiyama H, Kanamori T, Tsuchiya T. A case report of pancreatic inflammatory cyst with obstructive jaundice and duodenal obstruction, successfully recovered by endoscopic doranage via duodenum. Gifuken Ishikai Igakkai Zasshi (Journal of Gifu Medical Association) 15: 103-107, 2001 (in Japanease).

The Internal Medicine is an Open Access journal distributed under the Creative Commons Attribution-NonCommercial-NoDerivatives 4.0 International License. To view the details of this license, please visit (https://creativecommons.org/licenses/ by-nc-nd/4.0/).

(C) 2019 The Japanese Society of Internal Medicine Intern Med 58: 2485-2494, 2019 